Article

\title{
The Regulation of Sustainability Information-The Contribution of Directive 2014/95
}

\author{
Cristian Carini ${ }^{1, *}$, Laura Rocca ${ }^{2}$, Monica Veneziani ${ }^{3}$ and Claudio Teodori ${ }^{3}$ \\ 1 Department of Law, University of Brescia, Contrada Santa Chiara, 50, 25122 Brescia, Italy \\ 2 Department of Law, University of Brescia, Contrada Santa Chiara, 50, 25122 Brescia, Italy; \\ laura.rocca@unibs.it \\ 3 Department of Economics and Management, University of Brescia, Contrada Santa Chiara, 50, 25122 \\ Brescia, Italy; monica.veneziani@unibs.it (M.V.); claudio.teodori@unibs.it (C.T.) \\ * Correspondence: cristian.carini@unibs.it
}

\begin{abstract}
The Directive 2014/95, in force in 2017, is the first European step that requires mandatory non-financial information to undertakings (all "public interest entities" with more than 500 employees). The regulation is concerning sustainability information as environmental, social and employee, human rights and anti-corruption and bribery matters and disclosure of diversity policy for board members. The study, in the strand of the regulation of accounting, part of the broader field of research into accounting regulation, contributes to the debate on the quality of regulation, in this specific case referred to sustainability disclosure. The regulation of sustainability matters is studied in literature broadly in a post-implementation phase and at national level. This research, instead, aims to analyse, through the causal chain of regulatory policy, in the ex-ante stage, the quality of the regulation and, at least, the usefulness of the normative pressure. The Oil \& Gas sector is chosen as sample of the study, because it is one of the most advanced sectors in sustainability disclosure. The examination of the law, in terms of content requirements (what) and location of information (where), is the basis to apply the disclosure-scoring system, a partial form of content analysis, to the reports of the sample. The findings reveal a good level of completeness of non-financial information, however, there are some areas that have to be improved to reach the requests of the Directive. Results show also the presence of overlap between financial reports and sustainability ones. In conclusion, the regulation is useful to prompt undertakings to reflect on their reporting and so doing improve their sustainability approach.
\end{abstract}

Keywords: sustainability reporting; non-financial information; corporate social responsibility; accounting regulation; directive 2014/95; oil \& gas

\section{Introduction}

In October 2014 the European Union issued the Directive 2014/95 known as Directive on disclosure of non-financial information for large undertakings and groups (all "public interest entities" with more than 500 employees). Said Directive, in force since 2017, amended the previous Directive 2013/34 which defined the Framework of the Management Commentary and imposed on large-sized undertakings the drafting and publishing of a non-financial statement (NFS) referring to sustainability disclosure. Briefly, the Directive has an effect on the aspects concerning information contents, thus promoting the completeness of sustainability information and, as concerns the organizational aspects, requires all information to be communicated in a structured way in the undertakings' reporting system, either in a section of the financial report or by means of a separate report.

This study can be collocated in the strand of the regulation of accounting, part of the broader field of research into accounting regulation, with the intent to contribute to the debate on the quality of regulation, in this specific case referred to the improvement of sustainability disclosure. In 
particular, in the sphere of the causal chain of the regulatory policy $[1,2,3,4 ; 5]$, the study deepens the ex-ante stage the production of new regulation, attempting to understand the expected impacts.

Aim of the analysis is therefore the evaluation of the effectiveness of the Directive in harmonizing the sustainability disclosure along the reference lines of the content (what) and the organization of the information among the company reports (where). The empirical analysis has been carried out in the Oil \& Gas sector, since it is considered evolved in terms of disclosure $[6 ; 7 ; 8]$. To this end, the study proposes a replicable research methodology.

The analysis therefore sets out to reply to these RQs:

RQ1: What was the completeness degree of sustainability disclosure before the Directive entered into force?

RQ2: What is the organization of the sustainability disclosure to be evaluated in relation to the information overlapping of the financial report (FR) and the sustainability report (SR)?

After having disclosed the theoretical background and having carried out a review of the current state of researches (par. 2), by following the causal chain of the regulatory policy, the objectives defined by the regulation are examined (par. 3); a definition is given of the methodology developed to analyse the communicative behavior assumed by the undertakings before the entering into force of the regulation (par. 4); the effectiveness of the Directive in harmonizing the sustainability disclosure (par. 5) are underlined, in a view of improving both the information completeness and the organization of information in the disclosure process. The study ends (par.6) with an overview on future achievable research areas by applying the research method adopted in our essay.

\section{Theoretical background}

Since the regulation of accounting is the strand of interest, the first aspect to be considered pertains to the role of accounting in sustainability disclosure, which has been examined in depth in the Literature according to two different perspectives [9]. The first, of critical nature, maintains that the concept of sustainability has not been fully understood by the undertakings: any accountability instrument resting on a not internalized concept is therefore scarcely useful both inside the undertaking and outside of it $[10,11]$. The second perspective is the managerial one, according to which the corporate social responsibility (CSR) is considered a decision-making instrument of the undertaking [12], enabling the managers to have more information available, in addition to financial information, to be reasoned upon and allowing conscious decisions. According to this second perspective, the sustainability report is an instrument of legitimization and communication towards the internal and external stakeholders [13] with the aim of positioning the corporate activity in the social context where it operates.

There is also a successive point of view, more recent than the previous ones, according to which Baker and Schaltegger [14] consider the CSR in the sphere of pragmatic philosophy. According to this point of view, the CSR cannot be considered univocally and be assigned only one purpose a priori; on the contrary, it must be identified with the pragmatic behaviour of the undertaking and, therefore, can take on different roles in view of the operative objective it pursues. In this sense, the SR can take on the role conferred upon it by the compiler or said role can be established in the perspective of specific users or, again, the SR can be used to create a new communication channel with the stakeholders differing from that defined in the financial statements. In other words, said report is an instrument to understand what the undertakings are doing, in concrete, regarding the topic CSR.

According to Baker et al. [14], this study considers the CSR as an instrument in understanding "whether reports accurately represent organisational activities". This point of view is in line with the objectives of the regulation (Directive 2014/95) which asks the undertakings to disclose the non-financial information, in order to render understandable the actual impact of business on society and on medium-long term global development (effective communication in terms of CSR). 
As described, the effective disclosure of the CSR requires the evaluation of two inter-related aspects relevant to the information content (what) and the organization of information in the reporting system (where).

Since 1980 many surveys have been dealing with the comprehensiveness of the SR [9] besides the various initiatives promoted at international level to define the non-mandatory standards on the subjects pertaining to CSR. Some examples are given below [8]: IFAC Sustainability Framework 2.0; ESG Framework and KPIs for ESG; SustainAbility Global Reporters Program; AccountAbility's AA1000 Standards; ISO 26000 - Guidance on social responsibility; IRCSA - Framework for Integrated Reporting; Guidelines of Global Reporting Initiative (GRI) Standards; The International Framework Integrated Reporting of International Integrated Reporting Council (IIRC).

In literature, the academic surveys have analysed the content of the sustainability disclosure under various points of analysis:

- the level of detail of the information of CSR and the determinants of disclosure [15,16];

- the mostly emphasised areas of interest (i.e. environmental, social, diversity) and the space set aside for the main variables [17];

- the visual content of the SR, in terms of images and photos (visual communication) [18];

- the compliance of the SR with the previously mentioned guidelines [19] or the compliance with specific national legislations [i.e. the French instance 20, 21];

- the quality of the disclosed information and of the SR [22,23].

The wide variety of surveys on the analysis of CSR's disclosure content has been developed by implementing different research methods (i.e. disclosure index, KPI, quality, content analysis). Nevertheless, no survey on the quality of the regulation of accounting relevant to CSR has been carried out. This research area is underpinned. According to Sahabana, Buchholtz and Carroll [24], a new research area is the analysis of the role and the influence of the government (for us the European Union) on the institutionalization of the sustainability disclosure, consisting in the evaluation of whether the formal coercive pressure [25] modifies, and how, the attitude of the undertakings towards the SR. Also Hahn and Kühnen [26] indicate the role of the regulation on themes pertaining to sustainability as a future research area to be examined in depth. Finally, Habec and Wolkian [22], in their analysis on the quality of SRs in some European countries came to the conclusion that where the national legislation imposes legal obligation of sustainability disclosure, this will improve the quality of the SR.

With regard to the second line of research, i.e. by taking into account the organization of the information (where), we noticed that there are various instruments available to communicate the sustainability information. In literature, researchers initially studied the non-financial information stated in the financial reports $[27,28]$. Subsequently, research focused on stand-alone SRs and, finally, the attention was directed to the integrated financial statements and the relations between the reporting systems (financial report and sustainability report) $[7,29,30,31]$.

Nowadays the communication of environmental and social information occurs not only through the SRs but also through media channels, social media, web sites [9]. Nevertheless, for the purposes of this research, due to the requirements of the Directive, the object of the analysis are the written reports (financial and sustainability reports). The written reports are indeed the preferential instrument of the stakeholders [32]. This because they are formal instruments, they are characterized by higher accuracy in their preparation and they are the result of accountability systems which very often foresee the recourse to national or international standards and are therefore considered more reliable. A large number of them are then submitted to external auditing.

In this context of different reporting systems (FR and SR) and with a proliferation of different documents (some enterprises make use of a separate report, others provide an embedded report) the risk is that the communication may not result transparent and clear, without useless prolixity or the decoupling of non-significant information, thus reducing the clarity of the documents for the users, above all external users, and making the comparison of information more complicated. 
In fact, the Directive under examination underlines that the objectives of the regulatory intervention, as concerns the organization of the information, focus on the accessibility of the non-financial information to the external users and promotion of the accounting harmonization as concerns the sustainability.

By jointly analyzing the content and organization of the reports, aim of this study is therefore to fill up the gaps in the area of study, analysing, in a prospective of regulatory policy, the extent of the impact of the European Directive (regulation/formal pressure) on the sustainability disclosure of the undertakings.

\section{Accounting regulation on sustainability in Europe: from voluntary disclosure to mandatory disclosure.}

The regulation of accounting on sustainability disclosure at European Union level is recent, although the Union showed its sensitivity towards this topic some years ago (Table 1).

The definition of the CSR suggested in the Green Book (2001) is: "the integration by the undertakings, on a voluntary basis, of the social and ecological concerns in their commercial operations and in their relations with the parties involved". By this definition, that has been the starting point, the regulator had clearly expressed his/her will to promote an approach to "sustainable" undertakings.

In 2011, the new definition of the CSR appears much more general and less accurate than the previous one "the responsibility of enterprises for their impact on society". In 2011 the European accountability process of the non-financial information starts by the Commission Communication "Single Market Act" in which the companies are requested to provide more and transparent information on the social and environmental aspects. The same request appears in the Communication dated October 2011.

The European Parliament, in its resolutions of the year 2013, acknowledges that the sustainability disclosure is important to [33]:

- pinpoint the risks for sustainability and increase the confidence of the investors and consumers;

- manage the transition to a global sustainable economy by combining long-term profitability, social justice and protection of the environment;

- measure, monitor and manage the results of the undertakings and the relevant impact on the society.

Besides, the intent of the Parliament, then set forth by the emanation of the Directive, consists in offering to all the investors and stakeholders a framework on the policies of the sustainability that is comparable at European level (accounting harmonization); as to the consumers, the Directive purports to offer easier access to information on CSR.

This process of sustainability disclosure regulation is at seed level in Europe. Over 16 years the EU passed from a concept of voluntary CSR (2001) to the request (in 2014, applicable as from 2017) of a mandatory non-financial information statement for the large enterprises.

The European scene is also characterized by different situations of the member states, each one in fact has created a large number of approaches to sustainability disclosure, that are often scarcely comparable. As a matter of fact, in most European countries there are no legal SR requirements apart from those relevant to the Modernisation Directive of 2003 stating that: "large undertakings shall to the extent necessary for a good understanding of their financial position - include in their annual reports the most important non-financial performance indicators for the company's business, such as information on environmental and employee interests, in the company's analysis of the development of its business and of its financial position" [34]. According to a survey conducted by the Federation of European Accountants, in 2008, the Directive 2003 had not improved the sustainability disclosure in financial reports [35]. Other countries instead have introduced some disclosure requirements regarding the sustainability in their national legislation; some examples are 
France, UK, Sweden and Denmark, where a regulatory obligation of sustainability disclosure already existed.

Table 1. Accounting regulation in Europe on sustainability

\begin{tabular}{|c|c|}
\hline Year & Items \\
\hline 1993 & $\begin{array}{l}\text { White paper "Growth, competitiveness and employment" - The } \\
\text { challenges and ways forward into the } 21 \text { st century" }\end{array}$ \\
\hline March2005 & Manifesto of European enterprises against social exclusion \\
\hline 1996 & $\begin{array}{l}\text { CSR Europe comes to life in Brussels: as implementation of J. Delors' } \\
\text { Manifesto (1995) and preferential interlocutor of the European } \\
\text { Commission }\end{array}$ \\
\hline March 2000 & $\begin{array}{l}\text { Lisbon Summit - Call for corporate social responsibility as instrument to } \\
\text { make "Europe a pole of excellence" }\end{array}$ \\
\hline December 2000 & Nice Summit - Approval of the Social Agenda \\
\hline June 2001 & Goteborg Summit - Strategy for Sustainable Development \\
\hline July 2001 & Green book of the Commission, with the first definition of CSR \\
\hline November 2001 & Brussels - Conference of the Belgian UE Chairmanship on CSR \\
\hline July 2002 & $\begin{array}{l}\text { Commission Communication, Corporate Social Responsibility: a } \\
\text { Business Contribution to Sustainable Development. }\end{array}$ \\
\hline February 2003 & $\begin{array}{l}\text { Forum multi-stakeholders to define the characteristics and obstacles to } \\
\text { the dissemination of the RSI }\end{array}$ \\
\hline March 2005 & Road map on sustainable enterprise \\
\hline March 2006 & Promotion of an "European Alliance for the RSI" \\
\hline April 2011 & $\begin{array}{l}\text { Commission Communication, "Single Market Act - Twelve Levers to } \\
\text { Boost Growth and Strengthen Confidence 'Working Together to Create } \\
\text { New Growth" }\end{array}$ \\
\hline October 2011 & $\begin{array}{l}\text { Commission Communication "A renewed UE strategy 2001-2014 for } \\
\text { Corporate Social Responsibility" - a new definition of CSR }\end{array}$ \\
\hline February 2013 & $\begin{array}{l}\text { Parliament Resolutions on "Corporate Social Responsibility: } \\
\text { accountable, transparent and responsible business behaviour and } \\
\text { sustainable growth" and on "CSR: promoting society's interests and a } \\
\text { route to sustainable and inclusive recovery" }\end{array}$ \\
\hline Directive 2013/34/EU & Non-financial and diversity information required \\
\hline Directive 2014/95/EU & Mandatory Non-financial statement for large undertakings and groups \\
\hline
\end{tabular}

In this European scene, the objective of the Directive 2014/95 is that of harmonizing the sustainability reporting system at European level both in terms of what information is to be communicated (what) and where they must be arranged (where). Of course, in the attainment of the objective, the European legislator leaves flexibility to the undertakings in terms of materiality of CSR issues but requests "certain minimum legal requirements" [33], i.e. allowing the possibility of using one's own SR as NFS, if present and if it meets all the requirements of the Directive. 


\subsection{The Directive $2014 / 95$}

After having outlined the evolution process of the sustainability disclosure in Europe, the study analyses the specific requirements of the Directive 2014/95 in order to reply to the research questions.

Firstly, the recipients of the regulatory requirement are the "public interest entities" who have a minimum number of 500 employees. This because, according to the EU's opinion, their impact is higher on the community and involves more Member States. This reflexion of the EU finds a validation in the literature: the first theoretical contribution with systematic characteristics on social responsibility of the economic activities, i.e. H.R. Bowen's thought, expressed in 1953 and to whom the paternity of the Corporate Social Responsibility has been unanimously recognized; H.R. Bowen raises the awareness that the undertakings, above all the big ones, are vital centres of power and, through strategies, decisions and pursued actions they involve and influence the totality of the surrounding society [36].

Secondly, in terms of content of the Directive, the document states: "The undertakings affected will be required to disclose information on several non-financial matters, to the extent necessary for an understanding of the undertaking's development, performance and position, and of the impact of its activities" [33]. The minimum level of non-financial information should concern the following matters or topics:
a. environmental;
b. social and employee;
c. respect for human rights;
d. anti-corruption and bribery;
e. diversity;
f. business model.

For each one of the topics (a. - d.) the undertakings shall provide:

a. the description of the policies, including due diligence processes implemented;

b. the outcomes of these policies;

c. the risks relating to those matters and how the company manages those risks;

d. the non-financial key performance indicators relevant to the particular business.

For any information foreseen by the Directive, the principle is "comply or explain".

At the base of the disclosure there shall be the concept of materialisation, this means, as pointed out in paragraph 8 of the preamble to the Directive [33], that information should be provided in "relation to matters that stand out as being most likely to bring about the materialisation of principal risks of severe impacts, along with those that have already materialised. The severity of such impacts should be judged by their scale and gravity". The materiality concept is explained in the Guidelines on non-financial reporting published by the European Commission ("Guidelines") [37]; it refers to goal that "A company should focus on providing the breadth and depth of information that will help stakeholders understand its development, performance, position and the impact of its activities. The non-financial statement is also expected to be concise, and avoid immaterial information".

Besides, the European legislator has added the point on diversity policy according to which the undertakings shall provide, in relation to administrative, management and supervisory bodies, the information relating to age, gender and educational and professional backgrounds, the objectives of that diversity policy, how it has been implemented and the results of its implementation in the reporting period". This requirement is not dependent on any level of significance or materiality.

The Directive does not provide any specification on the disclosure framework but permits the use of national, European or international frameworks, even though "details of the framework(s) relied upon should be disclosed". For international frameworks, it specifically mentions (in par. 9 of the preamble): the Global Reporting Initiative G.R.I. G4; the UN's Global Compact; the OECD's 
Guidelines for Multinational Enterprises; the International Labour Organisation's Tripartite Declaration of principles concerning multinational enterprises and social policy. The idea behind this approach is to best make use of the already existing tools and also to create bridges between the European and the international reporting - thereby making NFI (non-financial information) comparable [34]. The will of accounting harmonization of the European legislator is therefore clear. As concerns this point, critical comments should also be underlined, however. Szabo and Sorensen [38] claim that an approach to non-financial reporting based "on minimum harmonization, not supported by detailed rules and standards on the collection and the processing of information, is not likely to have a significant effect", above all as concerns the aim of improving the CSR.

Thirdly, as concerns the organisation of information (where), the Directive demands insertion of the non-financial statement in the management report. But this request is not expressed peremptorily; in fact, it gives the possibility to make use also of a separate report, but "the report must be published at the same time as the management report or not later than 6 months after the balance sheet date and is referred to in the management report". In other words, the external reader must understand clearly the path to follow for getting access to the information. In conclusion, the Directive allows to maintain two reporting systems (FR and SR), with an indication, in the management report, of the publication of the second one. On this point the Guidelines clarifies that this approach is based on the connectivity of information, so there could be different sources of information but that must be inter-related. For example, the NFS "may include internal cross references or signposting in order to be concise, limit repetition, and provide links to other information ...but cross referencing and signposting should be smart and user-friendly, for instance, by applying a practical rule of 'maximum one 'click' out of the report'".

\section{Research method}

\subsection{The methodology applied}

The first stage of the research activity was aimed at analysing different documents in order to find out and better define the information requested by the Directive subject matter of this survey. In this way, we managed to lay the foundation for the subsequent analysis and identify the theoretical reference framework that the undertakings have to face in these first steps of the accounting harmonization process in the field of non-financial disclosure.

In greater detail, the EU Directive 2014/95 and the specific requirements in terms of disclosure and organisation of the information were analysed initially. Due to the low level of specification of the EU Directive and in order to construe the information required, other studies and international guidelines were analysed in depth. Particularly, we considered: the GRI G4 Guidelines [39] and the IPIECA/API. These guidelines were used in a previous research [40;7] and also widely diffused for the drawing up of sustainability reports in the extractive petroleum companies. Furthermore, these guidelines are also recognised by the EU Legislator as important references for the compliance with the EU Directive. Finally, the previous research and studies on the extractive petroleum companies $[42,43,44,45,46,47]$ were analysed in order to better qualify the business model information required by the EU Directive.

To analyse disclosure we used a disclosure-scoring system [48, 49], i.e. an analysis technique that provides for the classification of the information in pre-selected categories and subsequent measurement of the related disclosure level. This technique is considered a partial form [50] of content analysis [51, 52].

More specifically, the research consisted of the following phases [48; 53]:

- analysis of the documents mentioned above, in primis the EU Directive 2014/95;

- identification, by the research group, of the categories, sub-categories and individual variables contained therein, in light of the findings of the previous study phase;

- construction of the disclosure-scoring sheet and definition of the rules for identification of the individual variables; 
- application of the investigation technique by two researchers on the same sample of financial statements - with particular reference to the sustainability section and the corporate governance section - and the SR report, by highlighting any differences in the findings. In this pre-analysis phase, in order to make the behavior of the researchers as uniform as possible, some modifications had to be made to the basic scheme, and only after having achieved $90 \%$ identity between the results we actually directed our efforts to the analysis of the documents pertaining to the study;

- analysis of the documents and application of the detailed rules defined in the pre-analysis phase, by attributing the score $0 / 1$ to each variable and considering all equally important in terms of disclosure. Within the compass of this analysis, we therefore decided to ascribe the same importance to each piece of information, in order to achieve "non-weighted" medium disclosure indices, unlike the methods adopted by many other authors [54]. This choice, elected also by other academics [55] was made, considering that: firstly, the establishment of "weighted" indices would have introduced personal additional elements in the analysis; besides, at present, there seems to be no generally accepted classification to report the most important information disclosed by the undertakings;

- identification of the data and subsequent processing of the results with the creation of a disclosure index and the overlapping index, in order to measure the level of information overlapping between the financial reporting and the SR report.

The individual variables used for the analysis of the documentation [7] amount to a total of 148, grouped into seven categories (Table 2): 1 ) environmental (24 variables); 2 ) employee (28 variables); 3) social (9 variables); 4 ) human rights (6 variables); 5 ) anti-corruption and bribery (9 variables); 6 ) diversity (3 variables); 7) business model (69 variables).

Variables from 1 to 5 are subdivided into the following four sub-categories, as foreseen by the Directive: a) policy pursued; b) outcome; c) risks; d) non-financial key performance indicators, whereas category no. 6 is subdivided into the three sub-categories requested by the Directive: a) policy pursued; b) outcome; c) background. The business model has no sub-categories.

Various researches on the disclosure indices are based on the general principles of content analysis. With regard to these indices, the most important problem is to evaluate the relations between quantity and quality of the disclosure. Indeed, Botosan affirms that "although important, assessment of the quality of the information is very difficult" [54]. In this research, we shall not investigate the quality of the disclosure [56] but the level of disclosure [57], by taking into account both the completeness of company information and the organisation of information, by underlining the overlapping level between the two documents under examination. While the completeness is measured by the presence of the variables in the reports investigated, the overlap is measured by the joint presence of the information in both the FR and SR and was assessed exclusively on the information included in the reports investigated. The best result attainable by a company is the maximization of the information completeness by minimizing the overlapping level.

\subsection{Research sample and documents analysed}

Oil \& Gas companies have been selected because of their special attention given to the financial and sustainability disclosures.

According to Shabana et al., 2016 [24]: “Member firms in industries with higher environmental impact would be more scrutinized by the general public. To be responsive to such challenges, they would be more likely to utilize sustainability report as a tool to manage their legitimacy challenges". So, firstly, these companies are largely involved in sustainability reporting and, due to the relevant social and environmental externalities they generate, these companies often draw up sustainability reports, over and in addition to the financial report. 
Table 2. The model of disclosure

\begin{tabular}{|c|c|c|c|}
\hline Categories & Subcategories & N. var. & Guidlines \\
\hline \multirow[t]{5}{*}{ Environmental } & & 24 & GRI G4 EN 1 - 34 \\
\hline & Policy pursued & 3 & \\
\hline & Outcome & 5 & \\
\hline & Risks & 4 & \\
\hline & Non-financial KPI & 12 & \\
\hline \multirow[t]{6}{*}{ Employee } & & 28 & GRI G4LA 1 - 11 \\
\hline & & & GRI G4LA 13-16 \\
\hline & Policy pursued & 10 & \\
\hline & Outcome & 6 & \\
\hline & Risks & 5 & \\
\hline & Non-financial KPI & 7 & \\
\hline \multirow[t]{6}{*}{ Social } & & 9 & GRI G4SO 1 -2 \\
\hline & & & GRI G4 SO 9 - 11 \\
\hline & Policy pursued & 1 & \\
\hline & Outcome & 6 & \\
\hline & Risks & 1 & \\
\hline & Non-financial KPI & 1 & \\
\hline \multirow[t]{5}{*}{ Human Rights } & & 6 & GRI G4 HR 1 - 12 \\
\hline & Policy pursued & 2 & \\
\hline & Outcome & 1 & \\
\hline & Risks & 2 & \\
\hline & Non-financial KPI & 1 & \\
\hline \multirow[t]{5}{*}{ Anti-corruption and bribery } & & 9 & GRI G4 SO 3- 8 \\
\hline & Policy pursued & 2 & \\
\hline & Outcome & 1 & \\
\hline & Risks & 5 & \\
\hline & Non-financial KPI & 1 & \\
\hline \multirow[t]{4}{*}{ Diversity } & & 3 & GRI G4 LA 12 \\
\hline & Policy pursued & 1 & \\
\hline & Outcome & 1 & \\
\hline & Background & 1 & \\
\hline Business model & & 69 & Literature review \\
\hline Total & & 148 & \\
\hline
\end{tabular}

Secondly, the Oil \& Gas companies, since they operate in different geographical areas, are subject to different national disclosure regulations. In fact, this sector has frequently been subject matter for analysis fostered by the bodies having powers of accounting regulation [58, 41, 44]. Finally, we enumerate specific guidelines on the topic sustainability [59,60].

Thirdly, the researches directed at investigating the disclosure support the evidence that Oil \& Gas is one among the most evolved sector in terms of sustainability disclosure. It ensues that the sector enables to test ex-ante the requirements of the Directive in terms of completeness and overlapping, in order to determine whether the accounting regulation may have (since 2017) a role 
in improving the sustainability, in a context that can be regarded as already mature in terms of communication [6].

The choice of only one sector is then linked to the concept of materiality, since the material issues of only one sector should be more homogeneous with respect to those of various different sectors. This is reflected also in the Guidelines that points out "Similar issues are likely to be material to companies operating in the same sector, or sharing supply chains" or "It may therefore be appropriate to directly compare relevant non-financial disclosures among companies in the same sector".

The analysis was conducted on the European extractive petroleum companies listed in the DJSTOXX 600 Europe index as from 30 June 2015. The analysed companies are reported in Table 3.

Table 3. The companies analysed

\begin{tabular}{lc}
\hline \multicolumn{1}{c}{ Companies } & Country \\
\hline BP & GB \\
ENI & Italy \\
Galp Energia & PT \\
Lundin Petroleum & SE \\
OMV & AT \\
Repsol YPF & ES \\
Royal Dutch Shell & GB \\
Statoil & NO \\
Total & FR \\
Tullow Oil & GB \\
\hline
\end{tabular}

The analysis was performed on the 2014' FR and SR reports appearing on the companies' web sites. The year 2014 was selected because it is consistent with the objectives of the analysis, since it aims at realising the ex-ante effectiveness of the Directive. To assure homogeneity, the authors have checked that all the SRs have been drawn up by following the same guidelines (GRI G4).

\section{Results}

The results of the analysis are illustrated in Table 4.

The analysis highlights a good degree of completeness (RQ 1) of the sustainability report on environmental, social, employee-related topics, the safeguard of the human rights and anti-corruption matters. The diversity, consistently with the requirements of the Directive, is examined more in-depth in the financial report. Finally, the information on the business model is dealt more in detail in the financial report, whereas that disclosed in the sustainability report serves exclusively as framework for a better comprehension of the previously mentioned information categories. The analysis is completed with the results obtained with reference to the information overlapping (RQ 2). This appears limited only with reference to diversity and business model which, as observed, are mainly disclosed by means of the financial report. Further evidence of the empirical analysis is the reduced overlap of the category social. For the remaining categories, i.e. environmental, employee, human rights and anti-corruption, the overlapping degree is about $30 \%$ on the average, as evidence that the topics are dealt with both in the sustainability and in the financial report. For these issues, the joint reading of the two reports, does not actually improve the disclosure degree in the SR.

Going into the substance of the information categories and in order to comment the results referred to the sub-categories, we noticed that in the sustainability report the closest attention is paid to the environment and, in particular, to policies (0.83). Lesser attention is paid to information completeness of the outcomes and the key performance indicators. The risks area, generally dealt 
with in an adequate manner also in the sustainability report (0.50), is addressed more exhaustively in the financial report (0.70). As concerns the environment, the results highlight a considerable overlap for the sub-categories: policies, risks and key performance indicators. The joint reading of the two - financial and sustainability - reports contributes instead to improve the disclosure degree of the outcome.

Table 4. The disclosure indexes results

\begin{tabular}{|c|c|c|c|c|c|}
\hline \multirow[t]{2}{*}{ Subcategories } & \multicolumn{2}{|c|}{$\begin{array}{c}\text { Completeness } \\
\text { FR }\end{array}$} & \multicolumn{2}{|c|}{$\begin{array}{c}\text { Completeness } \\
\text { SR }\end{array}$} & \multirow{2}{*}{$\begin{array}{c}\text { Overlap } \\
\text { Mean } \\
\end{array}$} \\
\hline & Mean & Std. Dev. & Mean & Std. Dev. & \\
\hline Environmental & 0.33 & 0.13 & 0.48 & 0.14 & 0.39 \\
\hline Policy pursued & 0.53 & 0.32 & 0.83 & 0.24 & 0.63 \\
\hline Outcome & 0.12 & 0.14 & 0.32 & 0.21 & 0.40 \\
\hline Risks & 0.70 & 0.23 & 0.50 & 0.31 & 0.36 \\
\hline Non-financial KPI & 0.23 & 0.18 & 0.44 & 0.16 & 0.33 \\
\hline Employee & 0.42 & 0.10 & 0.48 & 0.11 & 0.39 \\
\hline Policy pursued & 0.44 & 0.13 & 0.55 & 0.12 & 0.48 \\
\hline Outcome & 0.32 & 0.23 & 0.45 & 0.14 & 0.32 \\
\hline Risks & 0.52 & 0.19 & 0.34 & 0.16 & 0.23 \\
\hline Non-financial KPI & 0.41 & 0.13 & 0.51 & 0.2 & 0.44 \\
\hline Social & 0.19 & 0.16 & 0.52 & 0.16 & 0.21 \\
\hline Policy pursued & 0.10 & 0.32 & 0.20 & 0.42 & - \\
\hline Outcome & 0.27 & 0.22 & 0.75 & 0.23 & 0.32 \\
\hline Risks & - & - & - & - & - \\
\hline Non-financial KPI & - & - & - & - & - \\
\hline Human Rights & 0.38 & 0.18 & 0.55 & 0.19 & 0.41 \\
\hline Policy pursued & 0.70 & 0.35 & 0.95 & 0.16 & 0.74 \\
\hline Outcome & 0.30 & 0.48 & 0.10 & 0.32 & 0.33 \\
\hline Risks & - & - & 0.20 & 0.35 & - \\
\hline Non-financial KPI & 0.60 & 0.52 & 0.90 & 0.32 & 0.67 \\
\hline Anti-corruption and bribery & 0.37 & 0.20 & 0.53 & 0.11 & 0.43 \\
\hline Policy pursued & 0.25 & 0.26 & 0.55 & 0.16 & 0.25 \\
\hline Outcome & 0.30 & 0.48 & 0.60 & 0.52 & 0.29 \\
\hline Risks & 0.46 & 0.27 & 0.54 & 0.13 & 0.51 \\
\hline Non-financial KPI & 0.20 & 0.42 & 0.40 & 0.52 & 0.50 \\
\hline Diversity & 0.57 & 0.22 & 0.13 & 0.17 & 0.36 \\
\hline Policy pursued & 0.30 & 0.48 & 0.20 & 0.42 & 0.67 \\
\hline Outcome & 0.50 & 0.53 & 0.20 & 0.42 & 0.40 \\
\hline Background & 0.90 & 0.32 & - & - & - \\
\hline Business model & 0.48 & 0.09 & 0.16 & 0.06 & 0.16 \\
\hline Total & 0.39 & 0.10 & 0.41 & 0.08 & 0.34 \\
\hline
\end{tabular}


As regard to the employees, the undertakings tend to make use of the sustainability report to give information on policies, key performance indicators and the outcomes, although - as concerns the latter - the degree of completeness could be improved. Conversely, less attention is focused on risks. Also in this case, the information completeness on the risks related to the employees is improved by the joint reading of the sustainability (0.34) and financial reports (0.52). With reference to the category employee, the overlap is present and widespread in all the sub-categories.

As concerns the social matters, the mostly addressed category is that of the outcome, particularly emphasised in the sustainability report (0.75). Very scanty (policy pursued), or even absent (risks and non financial KPI), is the completeness of the remaining information subcategories. As concerns the outcome in the social category, a high rate of overlapping appears $(0.32)$ and this denotes that the undertakings get back to the same information in the SR and in the FR.

Definitely high in the sustainability report is the degree of completeness on the pursued policies for the protection of human rights and the non-financial KPI. Neglected are the remaining sub-categories. The outcomes are mainly addressed in the financial report, whereas the information on risks, capable of being improved, is presented in the sustainability report. As concerns the human rights, the overlap rate is high in the policy pursued (0.74) and non-financial key performance indicators (0.67), which are, however, the most complete. Conversely, the overlap is limited in the sub-categories outcome and risks which show also a lower degree of completeness.

With reference to the anti-corruption matters, the degree of completeness of the sustainability report is generally high for all sub-categories, even if the prevailing attention is on the outcomes (0.60). Risks and policies are anyway treated in-depth. The key performance indicators are more exhaustively disclosed in the SR. As concerns the anti-corruption matter, the presence of a high level of overlap in the subcategories risks $(0.51)$ and non financial KPI $(0.50)$ suggests the need to come up with a more effective organisation of the information for the external users.

As to the diversity, the completeness degree of the all sub cathegories is higher in the FR. The information that can be found exclusively in the financial report as regard the background and in the sustainability report disclosure pertain also to the outcomes and policies. Anyway, for these last two categories there is a high level of overlap ( 0.67 and 0.40$)$, which emphasizes that the joint reading of the two reports brings a limited increase in the level of information completeness.

\section{Conclusions}

In this survey aimed at assessing the quality of the Directive in the stage previously to the introduction of the regulatory obligation, in terms of expected impact on sustainability information, we have analysed the disclosure degree of the sustainability and financial reports. The analysis was conducted in the Oil \& Gas sector which is considered evolved in terms of disclosure. The analysis model has been developed on the basis of the Framework GRI G4 and, as concerns the business model, on the basis of the studies and specific researches for the sector under examination.

Two are the elements we have deepened and they characterise our survey: firstly we examined the content both of the sustainability and the financial report, with reference to the information requested by the Directive; secondly, we examined in depth the topic relevant to how information was organized, that is to say the information overlapping the two reports subject-matter of our survey. The model applied to the financial statements drawn up before the introduction of the Directive allows us to analyse what information gaps, if any, the European regulation would bridge by the introduction of "mandatory" provisions.

Based on the disclosure scoring system, the results confirm the good degree of completeness of the environmental, social, employee-related, human rights and anti-corruption information given by the sustainability report. Nevertheless, the results have proven that there is some information, even in a particularly information-sensitive sector on sustainability such as Oil \& Gas, that is still scarcely disclosed: the outcomes concerning environmental matters (one of the "material" topics of the sector under examination) and employee-related matters, the risks related to the social and human rights matters and the KPI on anti-corruption and bribery. Instead, the diversity and the business model are disclosed in the FR. Currently, that is to say before the Directive entered into force, the 
completeness of the information on sustainability was therefore achieved only by the combined reading of the two documents, the financial and the sustainability report.

The different behaviours among the undertakings were also observed. Certainly, with reference to the sustainability report, companies tend to be more homogeneous in terms of communication, whereas the heterogeneity is more evident with reference to the financial report. The subject areas social and diversity anyway continue to be characterized by extremely different communication choices among the undertakings.

Finally, the results underline the presence of information overlapping - sometimes very pronounced - between the two reports.

The results confirm the utility of the Directive and the opportunity within the European Union of having promoted the debate. In fact, the Directive can serve as incentive both on the completeness of the sustainability disclosure and on the organization of the reporting and, in this respect, facilitate the access to information by the stakeholders.

In fact, on one hand the Directive requires the submitting of a plurality of information on sustainability, thus exhorting a reflection on the completeness and exhaustiveness of the published reports. In the sector we examined, the Directive could decrease the standard deviation for the areas human rights and diversity.

On the other hand, the Directive requires sustainability disclosure to be either directly provided in the financial report or in a separate and well-structured document. The Directive could therefore optimize the organizational aspect of communication.

The effort imposed by the Directive can therefore lead the undertakings to revise and reconsider their approach to sustainability: the exercise will be new for those who have never drawn up a SR, whereas those who have already produced this information, perhaps in an uncomplete or fragmented way, can take the opportunity to start a revision process to the chosen approach. The regulation therefore takes on a proactive role, since it imposes a reflection on the part of the undertakings also on the ways of communication of the NFI. This may coincide inside the enterprises with a strategic moment of analysis of the policies concerning sustainability and concrete programming on the theme.

Surely, the results of the research suffer from some limitations. The analysis has been conducted on only one sector and the reduced number of observations do not allow any generalization of the conclusions. However, the model proposed in the research allows replication in other areas. Future research is needed.

In fact, the regulation of accounting develops both in the ex-ante phase and in the ex-post as well $[3,5]$. This survey focused on the ex-ante phase, aimed at understanding the effectiveness of the new regulation.

The model of analysis suggested in the study can therefore be used also in the ex-post assessment phase, i.e. in the time following introduction of the new regulation. The application of the model developed in the reports over the years following entry into force of the Directive will be required, in order to get a useful benchmark to assess the real effect of the accounting regulation.

Secondly, it will be useful to replicate the research method used in the study for other sectors than Oil \& Gas, which is generally considered among the most evolved in terms of communication.

Thirdly, the suggested analysis model can be used for national comparative analysis. In fact, the Directive has been transposed into the regulation of the various European countries, thus causing different choices and solutions.

Another application of the present model could be to the undertaking that are not subject to the Directive but that have a relevant impact on society, for example listed firms with less than 500 employee or private firms in certain sector (i.e. steel sector), because it could reveal the state-of-art ex-ante "a regulation" and so could lead to the analysis if the cost of adapting to normative pressure could be more that the benefit derived from.

Lastly, it will be interesting to understand whether the undertakings will decide to adopt the NFS as a document by itself, in addition to the documents already produced, or if they will prefer to 
integrate the information in only one document and the reasons for their choices, in order to further understand the outcomes resulting from the approach to "sustainability regulation".

Conflicts of Interest: The authors declare no conflict of interest.

\section{References}

1. Organisation for Economic Co-operation and Development. Framework for Regulatory Policy Evaluation, OECD Publishing: Paris, France, 2014.

2. Organisation for Economic Co-operation and Development. Regulatory Enforcement and Inspections, OECD Best Practice Principles for Regulatory Policy, OECD Publishing: Paris, France, 2014.

3. Coglianese C. Measuring Regulatory Performance, Evaluating the Impact of Regulation and Regulatory Policy, Expert Paper n. 1; OECD Publishing: Paris, France, August 2012.

4. Parker, D.; Kirkpatrick C. Measuring Regulatory Performance, The Economic Impact of Regulatory Policy: a Literature Review of Quantitative Evidence, Expert Paper n. 3; OECD Publishing: Paris, France, August 2012.

5. Radaelli C., Oliver F. Measuring Regulatory Performance, Evaluating Regulatory Management Tools and Programmes, Expert Paper n. 2; OECD Publishing: Paris, France, July 2012.

6. Dilling, P.F.A. Reporting on Long Term Value Creation. The Example of Public Canadian Energy and Mining Companies, Sustainability 2016, 8, 1-26. DOI. Available online: https://doi.org/10.3390/su8090938.

7. Carini, C.; Chiaf, E. The relationship between annual and sustainability, environmental and social reports. Corporate Ownership \& Control 2015, 13, 771-785.

8. Szczepankiewicz, E. I.; Mucko, P. CSR Reporting Practices of Polish Energy and Mining Companies. Sustainability 2016, 8, 126-143.

9. Montecchia, A.; Giordano, F.; Grieco C. Communicating CSR: integrated approach or Selfie? Evidence from the Milan Stock Exchange. J. Clean. Prod. 2016, 136, 42-52.

10. Gray, R. Is accounting for sustainability actually accounting for sustainability . . . and how would we know? An exploration of narratives of organisations and the planet. Account. Organ. Soc. 2010, 35, 47-62.

11. Aras, G.; Crowther, D. Corporate sustainability reporting: a study in disingenuity?. J. Bus. Ethics 2009, 87 (Suppl.), 279-288.

12. Schaltegger, S.; Burritt, R.L. Sustainability accounting for companies: catchphrase or decision support for business leaders?. J. World Bus. 2010, 45, 375-384.

13. O'Dwyer, B. Stakeholder democracy: challenges and contributions from social accounting. Bus. Ethics Eur. Rev. 2005, 14, 28-41.

14. Baker, M.; Schaltegger, S. Pragmatism and new directions in social and environmental accountability research. Acc. Audit. Acc. J. 2015, 28, 263-294.

15. Gamerschlag, R.; Möller, K.; Verbeeten, F. Determinants of voluntary CSR disclosure: Empirical evidence from Germany. Rev. Manag. Sci. 2010, 5, 233-262.

16. Roca, L.C.; Searcy, C. An analysis of indicators disclosed in corporate sustainability reports. J. Clean. Prod. 2012, 20, 103-118.

17. Idowu O. S.; Towler. A. B. A comparative study of the contents of corporate social responsibility reports of UK companies. Management of Environmental Quality: An International Journal 2004, 15, 420-437.

18. Rämö, H. Visualizing the Phronetic Organization: The Case of Photographs in CSR Reports. J. Bus. Ethics 2011, 104, 371-387.

19. Boiral, O. Sustainability reports as simulacra? A counter-account of A and A+ GRI reports. Account. Audit. Account. J. 2013, 26, 1036-1071. 
20. Chauvey, J.N.; Giordano-Spring, S.; Cho, C.H. \& Putten, D.M.. The Normativity and Legitimacy of CSR Disclosure: Evidence from France. J. Bus. Ethics 2015, 130, 789-803.

21. Cho, C.H.; Michelon, G.; Patten, D.M.; Roberts, R.W. CSR disclosure: the more things change...?. Account. Audit. Account. J. 2015, 28, 14-35, DOI. Available online: https://doi.org/10.1108/AAAJ-12-2013-1549.

22. Habek, P; Wolniak, R.; Quant, Q. Assessing the quality of corporate social responsibility reports: the case of reporting practices in selected European Union member states. Qual. Quant. 2016, 50, 399-420.

23. Sethi, S.P.; Martell, T.F.; Demir, M. J. An evaluation of the quality of corporate social responsibility reports by some of the world's largest financial institutions. J. Bus. Ethics 2017, 140, 787-805.

24. Shabana, K.M.; Buchholtz, A.K.; Carroll A.B. The Institutionalization of Corporate Social Responsibility Reporting. Business \& Society 2016, 1-29.

25. DiMaggio, P.; Powell, W. The iron cage revisited: Institutional isomorphism and collective rationality in organizational fields. American Sociological Review 1983, 48, 147-160.

26. Hahn, R.; Kühnen, M. Determinants of sustainability reporting: a review of results, trends, theory, and opportunities in an expanding field of research Review Article. J. Clean. Prod. 2013, 59, 5-21.

27. Gray, R.; Kouhy, R.; Lavers, S. Corporate social and environmental reporting: a review of the literature and a longitudinal study of UK disclosure. Acc. Audit. Acc. J. 1995, 8, 47-77.

28. Sobhani, F.A.; Amran, A.; Zainuddin, Y. Sustainability disclosure in annual reports and websites: a study of the banking industry in Bangladesh. J. Clean. Prod. 2012, 23, 75-85.

29. Incollingo, A.; Bianchi, M. The Connectivity of Information in Integrated Reporting. Empirical Evidence from International Context. Financial Reporting, 2016, 2, 55-78.

30. Patten, D. M. Lessons from the Third Wave: A reflection on the rediscovery of Corporate Social Responsibility by the mainstream accounting research community. Financial Reporting, 2013, 2, 9-26.

31. Marchini, P. L.; Tibiletti, V. Bilancio Sociale e valori di impresa; Edizioni Monte Università Parma: Parma, Italy , 2004; pp. 1-295; ISBN: 978878470929.

32. Kim, H.; Hur, W.M.; Yeo, J. Corporate Brand Trust as a Mediator in the Relationship between Consumer Perception of CSR, Corporate Hypocrisy, and Corporate Reputation. Sustainability 2015, 7, 3683-3694.

33. Directive 2014/95/EU of the European Parliament and of the Council of 22 October 2014 amending Directive 2013/34/EU as Regards Disclosure of Non-financial and Diversity Information by Certain Large Undertakings and Groups. (Accessed May 2017).

34. Federation of European Accountants. EU Directive on disclosure of non-financial and diversity information. Achieving good quality and consistent reporting. Position Paper 2016.

35. Federation of European Accountants. Sustainability Information in Annual Reports - Building on Implementation of the Modernisation Directive. Discussion Paper 2008.

36. Bowen, H. R.. Social responsibilities of the businessman; Harper: New York, 1953; ISBN 978-1-60938-196-7.

37. European Commission, Communication from the Commission. Guidelines on non-financial reportingMethodology for reporting non-financial information. Draft 2017, available on line: https://ec.europa.eu/info/publications/170626-non-financial-reporting-guidelines en. (Accessed June 2017)

38. Szabó, D.G.; Sorensen K.E. New EU Directive on the Disclosure of Non-Financial Information (CSR), Eur. Co. E Fin. L. Rev. 2015, 12, 307-316.

39. Global Reporting Initiative. May 2013. G4 Sustainability Report Guidelines, GRI. Available Online: https://www.globalreporting.org/information/g4/Pages/default.aspx. (Accessed on May 2017).

40. Brammer, S.; Pavelin, S. Voluntary Environmental Disclosure By Large Uk Companies. J. of Bus. Fin. E Acc. 2006, 37, 133-152. 
41. Financial Accounting Standard Board. Improving Business Reporting: Insights Into Enhancing Voluntary Disclosures, 2001.

42. Pricewaterhousecoopers. Drilling deeper. Managing value and reporting in the petroleum industry. 2002.

43. Quagli, A.; Teodori, C. L'informativa volontaria per settori di attività; FrancoAngeli: Milano, Italy, 2005; pp. 1443; ISBN: 88-464-6938-0.

44. Security and Exchange Commission. Regulation S-X, Rule 4-10 Financial Accounting and Reporting for Oil and Gas Producing Activities Pursuant to the Federal Securities Laws and the Energy Policy and Conservation Act of 1975. 2005.

45. Canadian Security Administrators. National Instrument 51-101 Standards of Disclosure for Oil and Gas Activities, 2006.

46. Carini, C. Il business report di settore. Ruolo informativo e principi di predisposizione; Giappichelli: Torino, Italy, 2009; pp. 1-193; ISBN: 9788834897355.

47. World Intellectual Capital Initiative. Oil \& Gas Sector WIKI KPIs. 2016. Available online: http://www.wici-global.com/kpis (Accessed on June 2017).

48. Robb, S.W.G.; Single, L.E.; Zarzeski, A. Non Financial Disclosure Across Anglo-American Countries. J. of Intern. Acc. 2001, 17, 30-47.

49. Vanstraelen, A.; Zarzeski, M.T.; Robb, S.W.G. Corporate Non Financial Disclosure Practices And Financial Analysis Forecast Ability Across Three European Countries. J. of Intern. Fin. Manag. and Acc., 2003, 14, 249-278.

50. Beattie, V.; McInnes, B.; Fearnley S. A Methodology for Analysing and Evaluating Narratives in Annual Reports: a Comprehensive Descriptive Profile and Metrics for Disclosure Quality Attributes. Accounting Forum 2004, 28, 205-236.

51. Kassarjian, H.H. Content Analysis in Consumer Research. Journal of Consumer Research 1977, 4, 8-18.

52. Krippendorff, K. Content Analysis: An Introduction to its Methodology; Sage Publications: New York, USA, 2013; pp. 1-456; ISBN 9781412983150.

53. Bendotti, G.; Carini, C.; Teodori, C.; Veneziani, M. Content and quality of information: analysis of the management discussion session in the Italian financial reports in the period 2003-2008. Corporate Ownership \& Control 2013, 10, 248-264.

54. Botosan, C.A. Disclosure Level and the Cost of Equity Capital. The Acc. Rev. 1997, 72, 323-349.

55. Cooke, T.E. Disclosure in the Corporate Annual Reports of Swedish Companies. Acc. and Bus. Research $1989,19,113-122$.

56. Diamond, D.W.; Verrecchia, R.E. Disclosure, liquidity and the cost of capital. Journal of Finance 1991, 66, 1325-1355.

57. Marston, C.L.; Shrives, O.J. The use of disclosure indices in accounting research: A review article. British Accounting Review 1991, 23, 195-210.

58. American Institute Of Certified Public Accountants. Improving Business Reporting. A Customers Focus. Meeting the Information Needs of Investors and Creditors, comprehensive report of the special committee on financial reporting (The Jenkins Report), New York. 1994.

59. International Petroleum Industry Environmental Conservation Association. Report No. 437. Oil and Gas Industry Guidance on Voluntary Sustainability Reporting, 2 ${ }^{\text {nd }}$ ed.; IPIECA: London, United Kingdom, 2010.

60. Global Reporting Initiative, May 2013. G4 Sector Disclosure Oil and Gas. Available Online: https://www.globalreporting.org/information/g4/sector-guidance/sector-guidance/oil-and-gas/Pages/defa ult.aspx. (Accessed on May 2017). 